\title{
The Health Tracker: An Entrepreneur's Journey
}

\author{
Professor Gil Brookins, Siena College, USA
}

\begin{abstract}
This case traces the exploits of a young wife and mother with lots of entrepreneurial ideas, and the challenges she faces as she attempts to market her business startups, but can't seem to close on any of her proposed ventures. A chance occurrence in helping a friend organize numerous Health records, treatments, prescriptions, and appointments leads to the roll-out of a series of prototypes of a product that seems to fit her skill set. She tries a bit of everything, with moderate personal success and satisfaction, but with little financial success. The product is drifting aimlessly, and just a she is plans to shut it down and move in another direction, a series of events breathes potential new life into her concept. Now a new set of decisions needs to be made.
\end{abstract}

Keywords: Entrepreneurship; Marketing; Business Start Up; Health Management

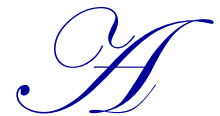

s Teri Haswell sat at her desk, surrounded by the collection of notes about business ideas, prototypes, reference materials, business books, and miscellaneous stuff, she recollected how she got were she was, and more importantly, where to go from here.

After two years of undergraduate college, and some work experience as an administrative assistant in a medical college, where she learned about patient care administration and computers, Teri got married and she and her husband settled into apartment above her grandparents. Unfortunately, both of the grandparents became gravely ill, and it fell to Teri to care for them. A year later Teri and her husband moved to New York City to follow his career, and where she completed an associate degree in business, and gave birth to the first of their three children soon after graduation.

As a stay-at-home mom, Teri spent much of her time with each of her children. She enjoyed "designing" toys and other children's products, even researched patents and, with the help of her father-in-law, built a prototype of a wooden toy consisting of knobs, locks, handles, and latches for toddlers to open and close. While she could see in her mind's eye her toy on store shelves, Teri realized she did not have the resources to make it a reality--they were a young and growing family with very limited resources, and Teri had no idea how to get the toy manufactured and distributed. She hadn't even considered how to market it. So, she gave up the idea, only to discover a year later a similar toy was being sold at local specialty toy shops at $\$ 75$ each!

Moving into their first house with her two children provided Teri with the inspiration for yet another child-related product. Teri was concerned the toddlers might get hurt playing around the brick fireplace hearth. After failing to find a guard in the children's safety catalogs and stores, she set out to design one of her own. Once again, Teri found herself at the local library researching patents on fireplace pads but had no success finding any patented hearth protectors. Convinced that there was an untapped opportunity, she began to sew a pad for her hearth, but quickly began running into obstacles. The pad had to be fireproof, which meant the material she had selected wouldn't work. And the finished product would have to fit different sized hearths. There were many manufacturing questions Teri simply did not know how to overcome and she did not know anyone else who could help. Again, she scrapped the idea of the fireplace guard. Less than a year later, she found herself ordering the "Hearthguard" from a catalog. She paid $\$ 60$ for a foam frame that was adjustable, fireproof and worked perfectly. While the product was just what she needed, reading the photocopied personal note inserted in the box was just another frustration. The use and care instructions included the following...from a "Mom, just like you, who realized her child might get hurt...so I decided to do something about it." 
It was the birth of another child to Teri's close friend that set off another entrepreneurial episode. Teri and her husband were expecting their third when her friend delivered a beautiful little girl, born with Cerebral Palsy. Almost from the beginning, the parents faced a mountain of health and insurance information; information that had to be organized, available, and transportable from doctor to doctor. The paperwork quickly overwhelmed the new parents. Teri suggested that there must be an organizer available for this type of information and helped them look for one. When no one was able to locate such a product, it occurred to Teri that she might have finally found the product that fit her skills. She was home with her three children, and a computer with a desktop publishing program on it. Her parents were in the printing and publishing fields and had many contacts in the industry. Teri quickly developed a prototype for her friend, and then spent more than a year designing what she called the "HealthTracker, A Health Information Organizer". It was a three ring binder that contained sections of forms for health care consumers to organize their personal and family medical histories and ongoing health situations.

Never intending to market HealthTracker herself, Teri called the editor of a consumer magazine. After a brief conversation, the editor indicated that he might be interested in publishing it. Teri drove to the company headquarters to meet with the editor, who was unfortunately not there. Instead she met with an assistant editor...a young man with a passion for computers who, appeared to be generally uninterested, noting that all of his health information was on his laptop! She knew right away that he was not in her target market and did not see the value of HealthTracker. After quickly ending the meeting, he climbed on his desk chair to get a book from an upper shelf to give Teri (as a sort of consolation prize). Teri casually asked him if anyone knew the password to his computer when he falls off his chair and is unconscious in the emergency room. He laughed, and then spent two more hours discussing how HealthTracker could be positioned in their product line. After three months of anxious waiting while the publisher did market studies, bad news came. The publisher was downsizing their book line and would not be able to pursue HealthTracker. Citing the possible difficulty in copyrighting a book of forms, the editor suggested Teri try self-publishing HealthTracker.

Teri's accepted the challenge. She bought books on running your own business and self-publishing. Health InfoManagement was established as her dba (doing business as) and she soon had a checking account, (with no money in it), and after a considerable effort, established a merchant account so she could accept credit cards from the millions of people who were going to call her and order HealthTracker. Teri assumed that getting her book manufactured would be the most difficult challenge and once she managed that, the book would sell itself because anyone hearing about it would naturally want it...word of mouth was the core of her "marketing plan".

Manufacturing turned out to be easy. There were several companies in the region that were willing to produce a professional prototype for free hoping for the business when it took off. The people at Brook Industries, in Rochester, New York, were very patient as they walked Teri through the process of determining the proper materials and colors for the books, the tabs and the contents. Their support helped her over a major hurdle. She was sure that once she introduced HealthTracker into the market, the orders would start rolling in.

Teri also found support in her local media. The newspaper ran a front page article on her new business and product and the television stations came to her home office and interviewed her, timing it with a publicized event at the local Barnes and Noble store. Teri was concerned about being able to fulfill orders at local retail outlets and her direct mail inquiries. Her worries were unfounded. There were many things she failed to consider. The books were too heavy and cumbersome, their vinyl covers quickly cracked at the seams, and they seemed too expensive for the market at $\$ 39.95$ retail selling price, and her cost per book was high. Local bookstores sold just fewer than 100 books over the next year. Teri found that if they ran out, she wasn't notified, she had to keep stopping into each to see if they needed more. It was more than she could handle as a mother of three young children.

Bolstered by the publicity garnered by the news story, Teri decided to give it one more try and redesigned the books to be smaller, lighter and more user-friendly. She used her family's savings to buy advertising in health magazines. She could only afford small classified ads in the classified sections so she decided the ads better shout at the readers to get their attention. She designed an ad with the headline, "How Did Your Grandmother Die? Knowing the answer to questions like this can save your life!" Feeling very clever, Teri hired a call center to take the orders...orders that never came. That was the end for her. 
Teri's husband suggested she complete her bachelor's degree in Marketing. Two years had passed since her dismal advertising attempt and Teri was disappointed by her failures and the time she "lost" trying to make her dreams come true. Eighteen years had passed since she first attended college and she felt she wasted her professional life by not completing her degree the first time, and building her career, even if it would have been working for others. Her husband had been very supportive over the years, and perhaps now was the time to get back on track.

Two months before she was to return to college, Teri was astounded to receive faxes ordering the HealthTracker from bookstores on the West Coast and in Canada. She hadn't made any effort to market the books in a long time! She discovered that the Internet was spreading the word for her. Barnesandnoble.com had included the HealthTracker in their database and bookstores were receiving requests for them. This wasn't enough to stop Teri from returning to school, but it was enough for her to make one last attempt to breathe life back into her idea. She sent her book to a local publisher, explaining that they were selling themselves and that if someone with the proper resources published them the HealthTracker had tremendous potential.

Months passed and Teri did not hear from the publisher. Back in college, this time in that "non-traditional student" category, Teri began to formulate new business ideas for herself. With the help of a marketing professor at her college, Teri introduced her books to his classes. The personal health organizer became a market research project for the semester for several student teams. The results were surprising. The student research teams found a whole new market in college students who live away from home or study abroad. The teams discovered that over $90 \%$ parents of college students polled on campus indicated they would like their child to have a health care organizer like the HealthTracker. By coincidence, there was a regional conference for college health care professionals not far from the College. Teri bought booth space and took her books to the conference where she introduced it to college health care providers. It was very positively received. It looked like HealthTracker was getting a second wind.

Teri was preparing herself to reestablish her business with her newly obtained marketing knowledge and contacts she had established while at college. To her surprise, she received an email from the publisher she sent the books to months earlier, asking if she was still interested, this time in selling her rights to the HealthTracker?

\section{AUTHOR BIOGRAPHY}

Professor Gil Brookins, Associate Professor, and past Chair of the Marketing and Management Department, has been a member of the School of Business full time faculty since 1986. Prof. Brookins' teaching and research interests focus on Marketing, Services, Retailing, and Entrepreneurship. Prof. Brookins has been active in the Eastern Academy of Management, and the CASE Association, as a reviewer, Roundtable participant, and Conference Research Session Chair. Professor Brookins holds Bachelor's and Master's degrees from the University at Albany, and a Certificate in Management from Harvard University.

\section{REFERENCES}

Allen, K. R. (1999). Launching New Ventures 2/e. Boston, MA: Houghton Mifflin.

Holt, D. H. (1992). Entrepreneurship: New Venture creation. Englewood Cliffs, NJ: Prentice Hall.

Kotler, P., \& Armstrong, G. (2016). Principles of Marketing 16/e. Boston, MA: Pearson.

Manning, J. \& Keller, K.L. (2004). Got Advertising that works? Marketing Management. January/February.

Peters, T. J. \& Waterman, R. H. (1982). In Search of Excellence. New York, NY: Harper \& Row.

Schindehutte,M., Morris, M. \& Pitt, L. (2009). Rethinking Marketing. Upper Saddle River, NJ: Prentice Hall.

Solomon, M. R., Marshall, G.W. \& Stuart, E.W. (2016) Marketing 8/e. Boston, MA: Pearson.

Wells, M. (2005). Have it Your Way. Forbes, February 14.

Zimmerer, T.W. \& Scarborough, N. M. (1996). Entrepreneurship and New Venture Formation. Upper Saddle River, NJ: Prentice Hall. 


\title{
TEACHING NOTE
}

\begin{abstract}
This case traces the exploits of a young wife and mother with lots of business ideas, and the challenges she faces as she identifies opportunities, and unmet needs, but can't seem to close on any of her proposed ventures. A chance occurrence in helping a friend organize numerous medical records, treatments, prescriptions, and appointments leads to the roll-out of a series of prototypes of a product that seems to fit her skill set. She tries a bit of everything, with moderate personal success and satisfaction, but with little financial success. The product is drifting aimlessly, and just a she is plans to shut it down and move in another direction, a series of events breathes potential new life into her concept. Now a new set of decisions needs to be made.
\end{abstract}

Intended Course(s), Level, and Topic(s): This case is intended to be used in an Entrepreneurship, New Ventures, or Product Development course at the undergraduate level. The case could be used early in the course to discuss personal characteristics, and challenges as a sole entrepreneur. The case provides opportunities for class discussion about need for understanding the market, need for understanding the industry you're in, building an effective team, and under- standing the impact of environmental forces on the enterprise. Could also be used in Intro courses in Marketing, Management, and in upper level courses in Research Methods.

Teaching Objectives: Depending on the Instructor's choice of use (see Teaching Suggestions below), the following objectives could be considered. Students should be able to:

- Perform a SWOT Analysis...applying SWOT to the sole entrepreneur in new product development.

- Understand the impact of environmental forces on business.

- Understand and apply the Marketing Mix.

- Develop a Marketing Plan for a new product.

- Complete an industry analysis, and use the results to provide guidance to the business owner as to risks and benefits of choosing among various alternatives identified.

\section{Discussion Questions:}

Is Teri an "Entrepreneur"?

Students will have varying viewpoints; this is an opportunity to force students to integrate the various theoretical positions offered in most texts, with the practical issues in the case, and their own personal perspectives. Most students see the effort, and perseverance as a key factors, others will raise issues about the lack of commercialization...ideas don't make an entrepreneur. This is a good opportunity to have students critically evaluate what they think about entrepreneurs.

Should Teri sell her rights to the "HealthTracker?"

Again, most students suggest she not sell, clinging to the heroic vision of an entrepreneur, while others see the major gaps in Teri's skill set, and the opportunity to grow the business through outside involvement. Students need to evaluate the best position for Teri...owning $100 \%$ of a struggling startup, or a lesser ownership position (including $0 \%$ if she sells, or is forced to cease operations). A SWOT analysis should help solidify positions.

What other market segments might be worthwhile targets to pursue?

In addition to the potential college student target (parents actually) other market segments might include the military, especially those service personnel with families who are most susceptible to frequent relocation, the "sandwich" generation, caring for children and aging parents, (and occasionally grandchildren, and health care 
providers/insurance companies who encourage patients to become more actively engaged in the management of their own health care.

Identify the key general environmental forces that impact the development of the HealthTracker. How can these be best managed?

Students always bring up technology, suggesting this should be an electronic diary/organizer, not print/paper based. This is a good discussion point, and forces them to think about how medical records are managed and disbursed currently, and into the future. What are the benefits of each? The risks? Other environmental forces - both macro and micro-include economic, social/cultural, demographic, competitive, legal/political, and global. A case can be made for an analysis of each.

Teaching Suggestions: This case has been used successfully as an opener to discuss the characteristics of the entrepreneur... are ideas enough, or must an entrepreneur actually implement "successfully"? It can be read before class, and students can bring in their analysis. An early use of the case provides the instructor with the opportunity to have the class "discover" all the issues in successful business development, actually brainstorming the Table of Contents of just about every Entrepreneurship text.

The case can also be used as a mini-project, especially related to industry analysis. If Teri self-publishes what will she encounter as challenges. How to source, how to distribute, i.e. mail/online ordering? Retail?

There are opportunities to have students develop a marketing mix analysis, and a marketing plan for the product?

Research Method/Disguise/Epilogue: This case was developed through extensive field-based research in conjunction with the principal owner, Teri Olsen. Minor disguise was incorporated in the case, primarily with the product name. Early on, the concept was named "HealthTrax", later it was re-named "The Personal Health Diary". Since Teri licensed her publication to Delmar Publishing, a division of Thomson, a slight disguise may keep students from quickly 'googling" some of the outcomes of the case. 


\section{NOTES}

